\title{
ИСТОРИЗМ В РУССКОМ ИСКУССТВЕ НА РУБЕЖЕ ХІХ-ХХ ВЕКОВ КАК СИМВОЛ НАЦИОНАЛЬНОЙ ИДЕНТИЧНОСТИ
}

Дубровская Г. Н.

И странным виденьем грядущуей поры Вставало вдали все пришедшее после.

Б. Пастернак

\section{ВВЕДЕНИЕ}

Рубежные периоды вольно или невольно сопряжены с ощущением перехода за грань, на новый уровень отношений в государстве, обществе. Нередко в эти периоды случаются войны, революции, обострение отношений между людьми и государствами. Так бывало не раз на протяжении истории, включая и современный нам рубеж XX-XXI веков. По мере удаления тех или иных исторических событий или явлений, особенно с уходом их свидетелей или очевидцев, искажаются факты, даты и т.п. И если достижения технического прогресса в XX веке подарили миру такие удивительные явления, как кинематограф, аудио- и видеосъемку, не говоря уже о невероятных возможностях компьютерной техники (и даже такие очевидные вещи, как документальное свидетельство, нередко представляют одни и те же факты в диаметрально противоположной трактовке), то в более ранние века, когда технические возможности были ограничены, роль «очевидца» и «летописца» выполняло искусство, особенно в произведениях, непосредственно затрагивающих историческую тематику. В этом отношении XIX век, особенно его последняя четверть и начало XX века, сыграли уникальную историческую роль. С одной стороны, отменено крепостное право, тяжким гнетом давившее на простой народ, в среде которого было много талантливых людей и в науке, и в искусстве; с другой - началось религиозное возрождение, давшее миру святых угодников и подвижников, что стало толчком к росту национального самосознания и воплощения его в творчестве. Неслучайно в один и тот же год с падением крепостничества (1861) в Петербурге А. Рубинштейн основал первую в России консерваторию, в которую набирали абитуриентов как из дворян, так и народных самородков. Это объединяло и призывало задуматься и о судьбах мира, и о собственной судьбе, отсюда - стремление возвратиться к истокам, к первопричине, как бы духовно очиститься. «Человек, живя в мире, думал о мире в целом... 
Церковь была микромиром, и вместе с тем, она была макрочеловеком... Большой мир и малый, Вселенная и человек! Все взаимосвязано, все значительно, все напоминает человеку о смысле его существования, о величии мира и значительности в нем судьбы человека»,- писал Д. Лихачев ${ }^{1}$.

\section{1. Расцвет русской культуры в конце XIX века на фоне духовного подъема в России}

Необычайный взлет русского искусства к концу XIX - началу XX века во многом был связан как с общим подъемом науки и культуры после падения крепостного права, так и с глубинными процессами в духовной жизни России. Поколение «семидесятников» воспитывалось в духе хранения национальных традиций, веры на фоне расцвета православного монашества и его феномена - старчества. «Есть в русской святости нечто с трудом определимое, но явственное. Оно и в русском почитании Божией Матери, и в почитании святых выражается. Может быть, это и наши иконы... это - наш золотой запас... Другая наша путеводная звезда, может быть, не в духовном, но в душевном, сердечном плане, это русская культура. И как высшее, наиболее яркое ее проявление русская литература... в лучшем, что ею создано, в основной ее тональности очень соответствует ... лучшему в русской истории... В ней нет гордыни, зато всегда присутствует острое чувство греха и покаяние... Русской культурой, русской литературой во многом будет меряться наше прошлое», - говорил прот. А. Шмеман 2 .

Еще с начала XIX века художественная интеллигенция и дворянство получали духовное наставничество, обращаясь за советом и благословением к старцам: в духовной переписке состояли М. Глинка со святителем Игнатием Брянчаниновым; А. Пушкин - с московским митрополитом Филаретом. В Оптиной Пустыни жили Н. Гоголь, К. Аксаков, братья И. и П. Киреевские, А. Хомяков; у старца Амвросия подолгу гостили обер-прокурор граф Толстой, великий князь Константин; возле старца жил Леонтьев. «Увидеть старца и поговорить с ним приезжали в Оптину пустынь А. Толстой, Ф. Достоевский с молодым Вл. Соловьевым. Л. Толстой писал: «Этот Амвросий совсем святой человек. Поговорил с ним, и как-то легко и отрадно стало у меня на душе. Вот когда с таким человеком поговоришь, то чувствуешь близость Бога» ${ }^{3}$. Сестра Л. Толстого перешла из Беляевского монастыря в Шамординскую общину, чтобы находиться под руководством о. Амвросия. Некоторые получали «профессиональное» религиозное

\footnotetext{
1 Лихачев Д. Великое наследие: Классические произведения литературы Древней Руси. Москва : Современник, 1980. С. 10.

2 Шмеман А. Основы русской культуры: Беседы на Радио Свобода. 1970-1971. Москва : Издательство Православного Свято-Тихоновского гуманитарного университета, 2017. С. 48-49.

${ }^{3}$ Кукушкин Л. История Православия : в 3 ч. Харьков : Фолио, 2010. С. 753.
} 
образование: философы П. Флоренский и С. Булгаков были православными священниками; композиторы, дирижеры: М. Балакирев, Н. Голованов, М. Ипполитов-Иванов, В. Калинников, А. Кастальский, Н. Римский-Корсаков, С. Рахманинов, П. Чесноков и другие - так или иначе связаны с Синодальным училищем (учились или преподавали).

Вместе с тем духовная парадигма рубежа XIX-XX веков сопряжена и с ультрасовременными направлениями в искусстве, и с культурой «Серебряного века», в которых сочетались определенный нигилизм, стремление вырваться вперед, сказать свое веское новое слово и ностальгия по историческому прошлому, что порождало и определенные противоречивые и кризисные явления. Как обычно, на переломные моменты истории приходится и «кризис интонаций», смена основных стилей, рождение новых жанров. О. Павел Флоренский ${ }^{4}$ говорил: «Весь стиль произведений эпохи определяется не индивидуальным произволом, даже не внутренним разумением и чутьем отдельного художника, а разумом истории, собирательным разумом народов и времен». Так, на грани XVIII-XIX веков классицизм уступил место романтизму; конец XIX - начало XX века ознаменовался переходом от романтического стиля к современным стилистическим направлениям: импрессионизму, экспрессионизму, символизму, неоклассицизму, модернизму и т. П. Кто-то из творцов стремился вырваться вперед, сказать, во что бы то ни стало свое новое слово, забыть о прошлом; ктото наоборот, не порывая связи с традицией и культурой минувшего времени, осовременивал их, создавая на этой основе свой собственный уникальный стиль. Отсюда неслучаен интерес к русской истории, особенно к древней. А история, как известно, предполагает фиксацию образа жизни народа, его культуру, традиции, религиозные верования и символику: чем глубже и ярче удается историку изобразить тот или иной период или эпоху, те или иные события, тех или иных героев, те или иные памятники или документы, - тем большей обобщающей силой насыщаются употребляемые им понятия, тем больше они превращаются в принципы или законы порождения изучаемой действительности, тем легче подводятся под них относящиеся сюда единичные явления, то есть тем больше исторические понятия становятся символами» 5 .

Русская история, a priori, неотделима от Православия, как бы признак русской национальной идентификации. Исследуя исторический путь Православия, прот. Александр Шмеман размышляет: «... спор о России есть одно из постоянных измерений русской истории. Россия принадлежит к числу тех стран и наций, которые спорят о самих себе. Никогда француз не просыпается утром, спрашивая себя, что значит быть

\footnotetext{
${ }^{4}$ Флоренский П. Богословские труды. Сборник 24. Москва : Издание Московской Патриархии, 1983. C. 105.

5 Лосев А. Логика символа. Философия. Мифология. Культура. Москва : Искусство, 1991. С. 157. 
французом... Русским же свойственно пребывать в постоянном напряженном искании смысла своего собственного существования» ${ }^{6}$. Это сказал человек, родившийся вне России, эмигрант во втором поколении, прочувствовавший на себе изнутри, что для русского зарубежья, эмигрантов и их детей Православный храм был единственной возможностью соприкосновения с исторической Родиной: «... в Белграде, Париже, Берлине или еще где-то, когда входили в русские православные храмы, которые были одновременно и храмами как таковыми, и местом, куда можно было прийти, чтобы прикоснуться к тому, чего эмигранты в своей катастрофе отделения от России были лишены ... даже те, кто никогда не бывал в России, тоже получали возможность ... через жизнь храма, церковную жизнь и связанную с ней жизнь бытовую приобрести опыт «русскости», опыт России, получив через Церковь «некое ее (России) воплощение, присутствие, ее частицу» ${ }^{7}$. О каждом из трех основных этапов в диалектике русской истории, связанных с Киевом, Москвой, Петербургом, существуют противоположные, исключающие одна другую оценки, выводимые из научного, исторического анализа: «Историю Русской Церкви невозможно выделить из истории России, как невозможно отделить ее и от ее византийского источника. Как Православие есть один из главнейших факторов в истории России, так и судьбы России определяют собою судьбу русского Православия. Поэтому всякая оценка или даже простое описание русского церковного пути поневоле включает в себя и определенное отношение к прошлому России ... полной истории русской религиозности доселе еще не существует... И наконец, мучительный вопрос о Церкви в России сейчас, значение самой России в судьбе мира - все это делает русскую тему бесконечно сложной» ${ }^{8}$ (курсив наш).

В русской исторической науке постоянно поднимаются вопросы, какое влияние на Руси было большим и основополагающим - греческое или болгарское (исходя из важности славянской письменности, основанной болгарами Кириллом и Мефодием), но тот или иной ответ на этот вопрос «не меняет основного факта в истории русского Православия, а именно - его органической связи с византинизмом, вопервых, и с византинизмом в его славянском «переводе», во-вторых... Долгое время киевский период «считался не более чем подготовительной, вводной главой истории «настоящего» расцвета Русской Церкви, связанного в русском сознании с Московским царством». Между тем в последние годы «киевский период все больше и больше признается, может быть, самым чистым, самым многогранным из всех

\footnotetext{
6 Шмеман А. Основы русской культуры: Беседы на Радио Свобода. 1970-1971 Москва : Издательство Православного Свято-Тихоновского гуманитарного университета, 2017. С. 20.

7 Там же. С. 23, 25. C. 349 .

Шмеман Александр, протоиерей. Исторический путь Православия. Москва : Паломник, 2007.
} 
периодов русской религиозности». Как говорил Г.П. Федотов (на лекции которого приходил, как известно, будучи в США, Сергей Рахманинов): «Киевская Русь - подобно золотым дням детства - никогда не померкла в памяти русского народа. В чистом источнике ее письменности всякий, кто хочет, может утолить свою духовную жажду; в ее писателях он может найти себе проводника сквозь трудности современного мира. Киевское христианство для русского религиозного сознания имеет то же значение, что Пушкин - для русского художественного сознания: значение образца, золотой меры, царского пути» 9 .

Ученые доказывают, что человек рождается с уже заложенной в нем генетической памятью, а отсюда следует, что некоторые способности и склонности также могут быть переданы по наследству потомкам, причем далеко не всегда прямым и близким и не всегда именно по той же профессии. Знаменательно, что неким связующим звеном между предыдущими и последующими поколениями своего рода является А.С. Пушкин и значение его для последующего развития русского музыкального искусства также неоценимо, как и развитие русской литературы послепушкинской эпохи. Выяснилось, что генетически по родовому древу А.С. Пушкин - предок многих выдающихся деятелей. Любопытные факты в документальном фильме «Древо жизни» (режиссер - С. Ерофеев) приводит исследователь генеалогии А.С. Пушкина А.А. Черкашин. Он обнаружил, что А.С. Пушкин - прямой потомок Святого благоверного князя Александра Невского в двадцать первом колене, а тот, в свою очередь, продолжает ветвь Святого равноапостольного великого князя Владимира, крестителя Руси; генетически связан со Львом Толстым, Николаем Гоголем, с историком Татищевым, с поэтами Кантемиром и Веневитяниновым; по музыкальной линии его наследуют С. Рахманинов и М. Мусоргский. И эта духовно-религиозная связь их между собой может быть указанием на провиденциальность этой линии гениев русского искусства.

Историки и литературоведы недавно пришли к весьма интересным выводам: исследуя творчество Александра Сергеевича, в частности сказки, которые во многом исходят от русского народного фольклора, его стилистики, символики, а также ряд других сочинений стихотворений, десятую главу «Евгения Онегина», они обнаружили поистине пророческие высказывания поэта, в которых можно проследить дальнейшую историю России и Православия. Эти пророчества даже сравнивают с «Катренами» Мишеля Нострадамуса. Например, таковы, по мнению исследователей, зашифрованные предсказания в поэме «Руслан и Людмила», в сказках: «О царе Салтане», «О мертвой царевне и семи богатырях», «О Золотом петушке». Некоторые исследователи даже

${ }^{9}$ Там же. С. $351-352$. 
усомнились в авторстве П. Ершова, говоря, что по стилю и манере изложения «Конек-горбунок» скорее всего принадлежит перу А.С. Пушкина. В этих сочинениях А.С. Пушкина множество числовой, цветовой символики. Можно соглашаться с этим или оспаривать, но, как бы то ни было, эти поэмы и сказки пронизаны духом русской старины. В них - призыв возродить славные моменты своей истории и национальныХ традиций. Этот процесс начинался еще в начале XIX века после разгрома Наполеона, когда русские творцы (поэты, музыканты, художники) ощутили насущную потребность восстановить национальную идентичность в противоположность западному влиянию, что особенно оформился к середине века.

Неудивительно, что идентичные художественно-эстетические взгляды разделяли представители различных видов искусства: с одной стороны, эти идеи «витали» в воздухе, а с другой - музыканты, художники, писатели общались между собой, нередко объединяясь в кружки, товарищества и т.П. Примерно в одно время (в конце 1850 -х - начале 1860-х годов) созданы «Товарищество передвижных художественных выставок» (поначалу именовавшееся «Артелью художников») и «Новая русская музыкальная школа» под руководством М. Балакирева, с легкой руки В. Стасова названная «Могучей кучкой». Но к концу века «балакиревский» кружок распался, а «передвижники» просуществовали до 1923 года, застав уже Советскую власть. И, несмотря на различный количественный состав и период существования «передвижников» и «кучкистов», взгляды их были близки: оба товарищества ратовали за возрождение и развитие национальной культуры, изображали историческое прошлое России и ее современность, картины народной жизни, являя новое направление в русском искусстве.

Вместе с тем, как часто случается, одно и то же событие различные люди воспринимают по-разному. Например, как в литературе шел спор между «славянофилами» и «западниками», определенная двойственность была в музыке: противостояние «Могучей кучки» (члены которой считали себя «националистами-народниками») «академистам» А. Рубинштейну и его последователям, к которым они причисляли и П. Чайковского. «Народники» в основном имели основную профессию, а музыка становилась своего рода их хобби. Они не заканчивали консерваторию, хотя принадлежавший к ним Н. Римский-Корсаков стал впоследствии профессором Петербургской консерватории, а потом даже ее директором.

«Кучкисты» черпали вдохновение в народных интонациях, в народном фольклоре, в сюжетах русской истории и т. п. «Академисты», в том числе П. Чайковский, больше озвучивали духовный и душевный мир человека, его переживания и страсти. Но было у них общее - 
обращение к православной символике: использование интонаций знаменного и других распевов, колокольности (композиторы светского направления, писавшие в то же время и храмовые песнопения, вольно или невольно переносили их интонации и в свои светские произведения) как своего рода показателю «русскости».

Общеизвестно, что в среде русской аристократия было модно изъясняться по-французски, а в музыке превалировало звучание итальянцев и немцев. Кризисным для русского искусства был «импорт» западных влияний еще в эпоху Петровских реформ (с одной стороны, расширение границ было положительным фактором, с другой - подрывало религиозные основы культуры), приведший к утрате высокодуховного искусства знаменного распева - основы Православного Богослужения. Б. Асафьев отмечал: «Резкий поворот к западноевропейскому инструментализму с его школьными нормами, почти механически перенесенными на русскую почву, вызвал сложный и длительный интонационный кризис», суть которого состояла в «совершенно ином методе слухового (интонационного) мышления-выражения: ведь были затронуты и мироощущение, и мировоззрение народа» ${ }^{10}$. Это понял еще М. Глинка, написав первую национальную оперу, воспроизведя в ней сюжет Отечественной истории («Иван Сусанин»).

И хотя «одни смотрели на Запад, другие на Восток, некоторые призывали к своеобразной изоляции и от Востока, и от Запада; одни видели спасение в усвоении технической цивилизации, другие - в углублении духовных, религиозных начал», это не означало «несамостоятельности, зависимости русского сознания от внешнего мира - это означает только, что наша культура всегда была, в лучших ее проявлениях, синтезом многих культурных традиций ... культуры нет без брожения, без спора, без трудного и творческого выбора» 11 (курсив наш). Ведь часто сама история являлась фоном для создания произведений искусства, их основой. Е. Назайкинский по поводу романса С. Рахманинова «Не пой, красавица» писал, что в нем «отражена русская действительность, какой она была до создания произведения. В ней уже существовали условия, необходимые для появления романса. Это - сложившийся до Рахманинова мир русской культуры и сознания, в котором большую сферу занимали интересы к национальному русскому, а с другой - к ориентальному ..., его отражения в русском сознании уже были закреплены в творчестве Пушкина, Лермонтова, Толстого и других писателей, художников, ученых» ${ }^{12}$.

\footnotetext{
10 Асафьев Б. Музыкальная форма как процесс: Книги первая и вторая. 2-е изд. Ленинград : Музыка, 1971. С. 217.

11 Шмеман А. Основы русской культуры: Беседы на Радио Свобода. 1970-1971. Москва : Издательство Православного Свято-Тихоновского гуманитарного университета, 2017. С. 56-57.

${ }^{12}$ Назайкинский Е. Логика музыкальной композиции. Москва : Музыка, 1982. С. 24.
} 
В это время особый интерес проявился к древнерусской иконописи, запечатлевшийся как в литературе, живописи, так и в музыке, иконописные черты: святость, ощущение пространства, света, воздушной и звуковой перспективы явили миру «Русский импрессионизм» и множество новых стилей и жанров, в которых сплелись и литургические черты, и древняя обрядовость, и историзм. Причем это не только коснулось светских произведений, связанных с религиозной тематикой, но и внесло изменения в характер и стиль духовных сочинений русских композиторов. «Отдавая должное гармоническому пению и в техническом отношении высокоразвитому в России, ... его изменившиеся направления всегда зависели от веяний своего времени» (курсив наш), писал регент Синодального хора С. Смоленский. Это требовало нового отношения к качеству репертуара, используемого как в практике богослужения, так и в духовных концертах. Аналогично высказывался А.В. Преображенский: «К разработке русской церковной музыки прилагается тот же исторический метод, какой привел к вполне благоприятным результатам русскую светскую музыку, так как на основе музыки европейской она развивалась в совершенно определенный национальный тип...». Русская церковная музыка получила возможность, «оставаясь в пределах исторически сложившегося типа, выйти на широкую дорогу свободного творчества, и, не разрывая резко в этом случае со своим прошльым, она уже вовлекает историческое наследие в условия современной музыкальной жизни и творчества» ${ }^{13}$ (курсив наш). При этом одно и то же явление и произведение воспринимаются в разные периоды совершенно по-разному, нередко совершенно не согласуясь с истинным замыслом его творца. История, можно сказать, переписывается в угоду идеологии того или иного общественного строя. Справедливо высказывание Е. Ручьевской по поводу «Хованщины» М. Мусоргского: «Идея «Хованщины» неоднократно перетолковывалась - в зависимости от господствовавших в обществе мировоззренческих установок. Это и мистический спектакль, и революционная опера» ${ }^{14}$.

Но очень часто именно перетолковывание «спасало жизнь» произведению. В частности, в советское время с его антиклерикальными установками перетолковывание позволяло «пропускать» сквозь цензуру церковно-обрядовые и молитвенные эпизоды в «Борисе Годунове», «Хованщине» и др. Это касалось переименования и переподтекстовки произведений, причем не только русской, но и зарубежной классики - от Г. Генделя (текст хора из оратории «Иуда Маккавей» в советское время звучал на украинском языке как «Праці хвала, хвала міцним рукам,

\footnotetext{
13 Русская духовная музыка в документах и материалах. Москва : Языки славянской культуры, 2002. T. IV. C. 663-664.

${ }^{14}$ Ручьевская Е.А. Работы разных лет : сборник статей : в 2 т. Санкт-Петербург : КомпозиторСанкт-Петербург, 2011. Т. II. С. 266.
} 
нехай лунає...») до С. Рахманинова: вместо «В молитвах неусыпающую Богородицу» - «В могилах неизвестных героев». Так же «Всенощное бдение» Рахманинова представлялось иллюстрацией старины. Вместе с тем, указывает С. Осадчая: «В том случае, если стиль уничтожен или искажен, говорить о подлинной художественности произведения невозможно. Устранение или подмена хотя бы части условий жсизни (курсив мой) произведения лишает его жизни и даже приводит к прямой противоположности - к антихудожественности» ${ }^{15}$.

Литургическая символика вошла не только в оперу, но и в вокальнохоровые, в симфонические произведения русских композиторов. Нередко она была самостоятельной «единицей», иной раз бралась в качестве цитаты. У С. Рахманинова, как и в обращении с фольклором, характерном для всей русской классической музыки, «цитата вживлена в собственный стиль, - знаменный распев включен в стиль как его органическая часть, как стилевая предпосылка» ${ }^{16}$ (курсив наш). М. Мусоргский использует для этого одноголосную фактуру наряду с фонизмом. «Сведение голосов фактуры до минимума создает впечатление отнюдь не пустоты, а, наоборот, огромной ладофункциональной и мелодической динамики в разреженном звуковом пространстве» ${ }^{17}$. В любом случае и цитирование православных интонаций, и некая «стилизация» под старину произведений русского искусства, увиденная глазами художников более близкого к нам периода, и воплощенная ими приобщают нас, людей уже XXI века, и к той далекой, и более близкой нам истории. И в этом смысле историзм, запечатленный в искусстве на рубеже XIX-XX веков, становится своего рода «мостом» между прошлым и будущим (нашим настоящим).

\section{2. Историческая проблематика в русском искусстве как мост между прошлым и настояшим, как связь времен и символ национальной идентичности}

Исторические сюжеты волновали писателей, живописцев и музыкантов. Процесс возрождения русской истории и культуры продолжался и достиг вершины к концу века. В музыке это происходило в двух направлениях: с одной стороны, обращение к старине, к архаике, древним преданиям, сказаниям (М. Мусоргский считал «Иванову ночь на Лысой горе» русской, национальной: «Я вижу в моей греховной шалости самобытное русское произведение, не навеянное германским глубокомыслием и рутиной, а, как «Савишна», вылившиеся на родных

\footnotetext{
${ }^{15}$ Осадчая С. Цикличность как ключевое свойство функционирования богослужебно-певческой традиции. Муз. мистеитвво і культура. Вип. 23. Одесса, 2016. С. 232.

${ }_{16}$ Ручьевская Е.А. Работы разных лет: Сборник статей : в 2 т. Санкт-Петербург : КомпозиторСанкт-Петербург, 2011. Т. II. С. 270-271.

${ }^{17}$ Исаева И. О мелодической природе гармонии и фактуры Мусоргского. Вопросы теории музыки. Вып. 3. Москва : Музыка, 1975. С. 137.
} 
полях и вскормленное русским хлебом», впоследствии - в «Хованщине»- Мусоргский держался тех же принципов, которые определились в «Ночи на Лысой горе» ${ }^{18}$ ); с другой - особое внимание к церковной тематике и православно-церковному пению и колокольности. В некоторых случаях эти две тенденции совпадали, создавая особый «православный» колорит и стиль. Например, для музыкального языка М. Мусоргского характерно слияние двух контрастных начал: «мелодической концентрированности, подчеркнутости мелодических контуров музыкальной ткани и особой фонической интенсивности гармонии... По сравнению с великими мелодистами разных времен и стран, такими, как Моцарт, Шуберт, Шопен, Глинка, Чайковский, Рахманинов, Прокофьев, принцип «мелодической концентрированности» не у всех становится «стилистическим принципом», как у Мусоргского, для которого это было «своеобразным выражением эстетической позиции в искусстве, раскрывающейся в сознательном стремлении художника 60-х годов прошлого века к максимальной близости народным истокам, к претворению тех черт национального искусства, которые представлялись наиболее родственными собственной натуре художника... Они «обнаруживают несомненное сходство с былинными и старинными церковными напевами, к которым, как известно, обращались композиторы Петербургской школы» ${ }^{19}$. М. Мусоргский сам собирал и изучал образцы старообрядческого пения. При этом «замыслу его отвечал не только характерный колорит древности, которым овеяны архаические песнопения», но сам «интонационный строй старинных вокальных жанров оказался предпосылкой мелодической интенсивности музыкального языка» ${ }^{20}$.

Интерес к истории был характерной чертой для представителей почти всех творческих профессий. И не удивительно, что они, общаясь между собой, как по системе сообщающихся сосудов, передавали его друг другу. Многих художников и музыкантов связывали узы взаимной симпатии, дружбы с прогрессивными писателями (И.С. Тургеневым, Л.Н. Толстым, Н.А. Некрасовым, В.М. Гаршиным, М.Е. СалтыковымЩедриным и другими), артистами (Ф.И. Шаляпиным, М.Г. Савиной и др.), учеными (Д.И. Менделеевым, С.П. Боткиным, И.П. Павловым). Целую галерею портретов выдающихся современников создали «передвижники»: Н.Н. Ге - Н.А. Некрасова, Л.Н. Толстого; И.Н. Крамской - А.Н. Островского; В.Г. Перов - Ф.М. Достоевского; И.Е. Репин М.П. Мусоргского, М. Горького, В.В. Стасова; В.А. Серов Н.А. Римского-Корсакова; Н.А. Ярошенко - П.А. Стрепетовой. О своих

\footnotetext{
18 Ручьевская Е.А. Работы разных лет : сборник статей : в 2 т. Санкт-Петербург : КомпозиторСанкт-Петербург, 2011. Т. II. С. 264.

${ }^{19}$ Исаева И. О мелодической природе гармонии и фактуры Мусоргского. Вопросы теории музыки. Вып. 3. Москва : Музыка, 1975. С. 132-134.

${ }^{20}$ Там же. С. 135.
} 
дружеских взаимоотношениях с В.В. Васнецовым, Д.А. Хомяковым, П.В. Жуковским вспоминал С.В. Смоленский.

В этот период на полотнах художников возникают исторические события и персонажи, в том числе библейские. Во многом это было связано с тем, что авторы параллельно работали в светской и церковной областях. Например, В. Верещагин сделал наибольшее количество росписей для Храма Христа Спасителя: алтарные полотна «Моление о Чаше», «Се человек», «Несение Креста», «Распятие», «Снятие с Креста», «Положение во гроб», вывезенные после уничтожения Храма в Петербург и хранившиеся в Казанском соборе. Принимал участие в строительстве Храма и скульптор П. Клодт, автор «Укротителей коней» на Аничковом мосту.

Противоречива фигура М. Врубеля, наряду с «Демоном» расписывавшего Кирилловскую церковь в Киеве. Знаменательны полотна А.В. Иванова «Явление Христа народу», «Явление воскресшего Христа Марии Магдалине»; В. Поленова «Христос и грешница»; И. Айвазовского «Тайная Вечеря», «Хождение по водам; С. Милорадовича «Черный собор»; И. Репина «Иван Грозный и его сын Иван», «Крестный ход в Курской губернии», «Протодиакон»; К. Савицкого «Встреча иконы»; И. Крамского «Христос в пустыне»; И. Прянишникова «Спасов день на Севере»; Н. Неврова «Княжна Юсупова перед пострижением».

Большое количество исторических и библейских сюжетов на полотнах Н.Н. Ге: «Тайная вечеря», «Что есть истина?», «Христос в Гефсиманском саду», «Суд Синедриона», «Христос в синагоге», «Голгофа», «Мария, сестра Лазаря», «Христос перед Анной», «Саул у Аэндорской волшебницы», «Возвращение с погребения», «Петр I допрашивает царевича Алексея Петровича в Петергофе», в 1874 году - «Екатерина II у гроба императрицы Елизаветы»; «Вестники Воскресения», «Выход Христа с учениками», «Разрушение Иерусалима», «Царь Борис и царица Марфа».

Множество исторических и библейских персонажей создал В.М. Васнецов: «Витязь на распутье» (1882), «После побоища Игоря Святославича с половцами» (1880). Знаменательно, что в это же время (1869-1887) и на этот же сюжет в течение 18 лет А.П. Бородин сочинял свою оперу «Князь Игорь». Как известно, смерть прервала работу над ней. В том же году В.М. Васнецов написал картины: «Вестники Апокалипсиса», «Нестор летописец» и «Княгиня Евдокия» (1893). Особенно плодотворным для В.М. Васнецова был 1896 год, когда появились «Крещение Руси», «Бог Саваоф», «Страшный суд», «Блаженство рая», «Христос Вседержитель», «Распятие Иисуса Христа», «Ангел с лампой», «Собор святителей Вселенской церкви». Истори- 
ческую линию продолжили картины: «Богатыри» (1898), «Встреча Олега с кудесником», «Прощание Олега с конем», «Гусляры» (1899).

Подобные образы вдохновляли В.И. Сурикова: «Боярыня Морозова», «Искушение Христа» (1872), «Изгнание торгующих из храма» (1873), «Пир Валтасара» (1874), «Первый Вселенский Никейский собор» (1876), «Утро стрелецкой казни» (1881), «Меншиков в Березове» (1883), «Боярышня» (1886), «Взятие снежного городка» (1891), «Покорение Сибири Ермаком» (1895), «Переход Суворова через Альпы» (1899).

К историческим сюжетам обращались и русские композиторы. Исторические сюжеты высвечиваются у П.И. Чайковского: в «Орлеанской деве», «Мазепе», «Опричнике»; у «кучкистов»: в «Хованщине» и «Борисе Годунова» М. Мусоргского, в «Князе Игоре» А. Бородина, в «Псковитянке», «Вере Шелоге», «Царской невесте» Н. РимскогоКорсакова. Русская церковная музыка получила возможность, «оставаясь в пределах исторически сложивщегося типа, выйти на широкую дорогу свободного творчества, и, не разрывая резко в этом случае со своим прошльлм, она уже вовлекает историческое наследие в условия современной музыкальной жизни и творчества» ${ }^{21}$ (курсив наш). По А.В. Преображенскому: «К разработке русской церковной музыки прилагается тот же исторический метод, какой привел к вполне благоприятным результатам русскую светскую музыку, так как на основе музыки европейской она развивалась в совершенно определенный национальный тип...».

В контексте «историзма» в русском музыкальном искусстве того периода ярким примером являются музыкальные «реставрации» А. Кастальского. В них автору, по мнению Б. Асафьева, удалось «развить, а не просто технически разработать, пользуясь чисто внешним образом заключенными в самом строении мелодии гармоническими, контрапунктическими и колористическими возможностями... так органично развивать и расширять, присовокуплять и соподчинять драгоценные обломки старинной музыки» 22 . К «историческим» можно отнести также и другие произведения А. Кастальского: «Чтение дьяком люду московскому послания патриарха Ермогена тушинским изменникам», «Кантата в память 1812 года», «300 лет» (царствования дома Романовых)». Неслучайно примерно в это время появилась Литургия «славного во всех областях музыки, любимца муз и публики C.В. Рахманинова», как писал А. Кастальский ${ }^{23}$, а чуть позднее его

\footnotetext{
${ }^{21}$ Русская духовная музыка в документах и материалах. Москва : Языки славянской культуры, 2002. Том IV : Степан Васильевич Смоленский. Воспоминания: Казань-Москва-Петербург / Гос. центральный музей музыкальной культуры им. М.И. Глинки. С. 663-664.

${ }^{22}$ Русская духовная музыка в документах и материалах. Москва : Знак, 2006. Том V : Александр Кастальский. Статьи, материалы, воспоминания, переписка. / Гос. ин-т искусствоведения, Гос. центральный музей музыкальной культуры им. М.И. Глинки. С. 266.

${ }^{23}$ Там же. С. 59.
} 
«Всенощная», о которой И. Гарднер сказал: «В новизне музыкальной фактуры слышится старина. От всего произведения веет настроением древних московских кремлевских соборов» ${ }^{24}$. То есть произведение для богослужебного пения настолько стилистически выдержано в древнерусской певческой манере, что отразило и «дух» русской истории. Но, помимо нее, среди произведений С.В. Рахманинова, опубликованных посмертно, есть и такие, которые непосредственно связаны с русской исторической тематикой: симфоническая поэма «Князь Ростислав» по стихотворению А.К. Толстого; оперные отрывки: «Два монолога из драмы А.С. Пушкина «Борис Годунов»: Монолог Бориса «Ты, отче патриарх...» для баса с фортепиано, Монолог Пимена «Еще одно, последнее сказанье» для тенора с фортепиано; «Квартет из «Мазепы». Позднее, уже в XX веке, историческая тематика ярким цветом расцветет в музыке С. Прокофьева: в его опере «Война и мир», в кантате «Александр Невский», в музыке к кинофильму «Иван Грозный» и др.

На рубеже XIX-XX веков эта тема была особенно актуальна: обращение к истории утверждало русскую национальную идентичность. Можно провести временные параллели некоторых произведений в прозе и музыке:

- в 1863 году Л.Н. Толстой начал работу над эпопеей «Война и мир» (писал он ее 7 лет, следовательно, завершена примерно в 1870 году);

- в 1864 году П.И. Чайковский написал музыку к сцене «Ночь. Сад. Фонтан» из трагедии А.С. Пушкина «Борис Годунов» для оркестра, в 1867 году - музыку к драме А.Н. Островского «Дмитрий Самозванец и Василий Шуйский», в 1868 году - оперу «Воевода»;

- в 1869 году создан «Борис Годунов» М.П. Мусоргского, а П.И. Чайковский переложил для фортепиано в четыре руки музыкальнохарактеристическую картину «Иван Грозный» А.Г. Рубинштейна;

- 1872 год: «Хованщина» М.П. Мусоргского и «Опричник» П.И. Чайковского, а также его Кантата в память двухсотой годовщины рождения Петра Великого;

- 1873 год - «Псковитянка» Н.А. Римского-Корсакова;

- в 1878 году - Литургия св. Иоанна Златоуста П.И. Чайковского, в 1881 году - Всенощное бдение и «Орлеанская дева», в 1883 году кантата «Москва» и опера «Мазепа», 1885 году - «Гимн в честь Св. Кирилла и Мефодия», 1887 году - хор «Ангел вопияше».

В 1888 году - «Воскресная увертюра на темы Обихода» «Светлый праздник» Н.А. Римского-Корсакова, а в «Летописи» он пишет, что в оркестровых произведениях этого периода - «Каприччио»,

\footnotetext{
${ }^{24}$ Гарднер И. Богослужебное пение русской Православной Церкви. Holy Trinity Monastery, Jordanville, 1977 г. Православный Свято-Тихоновский Богословский институт : в 2 т. Москва, 2004. Том II. C. 259.
} 
«Шехерезаде» и «Воскресной увертюре» - он использовал приемы, характерные для русского стиля, и оркестровка его «достигла значительной степени виртуозности и яркой звучности без вагнеровского влияния, при ограничении себя обыкновенным глинкинским составом оркестра... Исчезающий контрапункт заменяется сильным и виртуозным развитием фигураций» ${ }^{25}$.

В начале XX века также создавались картины недавнего прошлого и современности, запечатлевая для нас историю в красках. Среди них можно назвать картины В.И. Сурикова: «Степан Разин» (1906), Портрет А.В. Суворова (1907), «Разин» (1909), «Пугачев» (1911), «Благовещение» (1914), «Княгиня Ольга встречает тело князя Игоря» (1915); В.М. Васнецова: «Богатыри» (1915), «Архангел Михаил» (1915), «Георгий Победоносец» (1919); К. Юона - «Сергиев Посад» (1911), Б. Кустодиева «Масленица». На полотнах русских художников часто исторические сюжеты сочетались и перемежались с былинными и сказочными образами и персонажами.

Близка к историко-летописно-былинному жанру опера Н.А. РимскогоКорсакова «Сказание о невидимом граде Китеже и деве Февронии». Замысел воплощения сюжета о граде Китеже, укрытом водами озера Светлый Яр и спасенном от татарского нашествия, волновал композитора с середины 90-х годов, но воплощение получил в 1903-1904 годах. В опере мастерски сплелись легенды, летописи, древняя повесть о Февронии Муромской, былины, духовные стихи. Их объединил либреттист, прекрасный знаток древнерусской литературы В. Бельский, и в результате получилось одно из величайших и своеобразнейших явлений русского искусства, утверждающее величие патриотического подвига, идею верности Родине и любви.

Последняя опера Н.А. Римского-Корсакова, которую, к сожалению, композитору при своей жизни не удалось увидеть, - «Золотой петушок». И хотя по жанру это - сатирическая опера-сказка, но в ней как бы освещены события современной композитору истории и действующих персонажей, в частности в образе Золотого петушка подразумевался царь Николай Второй. По смелости гармонических находок и оркестровки это уже провидческий взгляд в музыку XX века. Неслучайно, С. Рахманинов, покидая Родину, взял единственную партитуру - «Золотого петушка». И некоторые идеи Н.А. Римского-Корсакова он творчески осмыслил в «Симфонических танцах».

Как видно, религиозные сюжеты вполне вписывались в историческую фабулу художественных и музыкальных произведений. «Внутренняя сущность» «Руслана» Глинки, по Асафьеву - «таинственное и

\footnotetext{
${ }^{25}$ Римский-Корсаков Н. Летопись моей музыкальной жизни. 9 издание. Москва : Музыка, 1982. C. 214-215.
} 
религиозное начало жизни... в культе «таинств» надо видеть и на нем утвердить глубинность и величие «Руслана» ${ }^{26}$. В нем выделяются два жанровых уровня: литургически-обрядовый и собственно оперный, что отразилось в соответствующей символике. Сказочность «Руслана» и историзм «Сусанина» проповедовали нравственные и общечеловеческие ценности: любовь, преданность, верность долгу, чести, семье, Родине, заботу о ближнем, которые эстафетно передались «наследникам» (если исходить из определения М. Глинки, как желудя), его молодым «дубкам».

Во многих русских операх можно выделить идеи христианской этики и морали, затрагивающие проблемы «маловерия», «покаяния», «смысла страданий», «отречения от мира», «политической и духовной свободы», «прощения врагов», «любви к Богу и ближнему», «сакрализации власти», «катастрофичности истории», «смысла творчества в истории» ${ }^{27}$, во многом связанное с параллельной работой большинства композиторов в церковной сфере, их знанием особенностей и канонов богослужения. Отсюда - неслучайное вкрапление в оперы церковных «сюжетов», например, сцена венчания на царство в «Борисе Годунове»; сцены, связанные с раскольниками, в «Хованищине», бой к заутрене в «Царской невесте», «Псковитянке»; сцены отпевания графини в «Пиковой даме». А «Сказание о невидимом граде Китеже» вообще было причислено к жанру «оперы-литургии» ${ }^{28}$. Но это и сугубо музыкальное сопровождение в вышеуказанных операх колокольностью (без участия колокола в качестве инструмента оркестра), имитируемой фонизмо-гармоническими оркестровыми средствами, и использование ее как символа; это также введение определенных узнаваемых «литургических» интонаций, ставших своего рода знамением эпохи, в одних случаях цитатно, в других «только фрагментарно, в виде отдельных «наметок», интонационных идей. Нередко это был отнюдь не намек, а явная связь с литературным текстом, словом, и русским, и церковнославянским, предтечей русского языка (что неоднократно подчеркивал Д. Лихачев) ${ }^{29}$, передавшего ему характерные черты: экфонетику (чтение нараспев синкрезис слова и музыки) и ямбичность, преобладавшую в русской поэзии рубежа XIX-XX веков (о чем писал А. Блок).

Пение в унисон - монодийность - символ единства Церкви используется как красочный, колористически-образный прием в инструментальных и оперно-симфонических произведениях: в хоровых

${ }_{26}$ Асафьев Б. Симфонические этюды. Ленинград : Музыка, 1970. С. 28.

27 Ситарская Ю. Религиозно-этическая проблематика и стилевые процессы в русской опере последней трети XIX - начала XX века: М. Мусоргский, Н. Римский-Корсаков : дисс. ... канд. искусствоведения. Киев, 2006. С. 40-52.

28 Орлов Г. Н.А. Римский-Корсаков на пороге XX века. Пути исканий. Bопросы теории $u$ эстетики музыки. Вып. 14. Ленинград : Музыка, 1975. С. 28-29.

29 Лихачев Д. Великое наследие: Классические произведения литературы Древней Руси. Москва : Современник, 1980. С. 136. 
эпизодах опер М. Мусоргского: «Борис Годунов», «Хованщина», Н. Римского-Корсакова: «Царская невеста», «Псковитянка», «Сказание о невидимом граде Китеже и деве Февронии», в которых историзм и литургийность идут рядом. Это касается не только вокально-хоровых, но и инструментальных жанров. Инструментально-симфонические примеры - «Богатырская» симфония А. Бородина, «Картинки с выставки» М. Мусоргского, Пятая, Шестая симфонии П. Чайковского, Вторая, Третья, Шестая, Седьмая симфонии, симфоническая картина «Кремль» А. Глазунова.

К историзму в русском искусстве можно отнести и библейские мотивы в поэзии С. Есенина, так называемой «есенинской библии», созданной уже в XX веке, которая вдохновила уже русского советского композитора Г.В. Свиридова: «Отчалившая Русь» («Иорданская голубица», 1918), «Симоне, Петр...» («Пришествие», 1917), «Там, за Млечными холмами...» («Пантократор», 1919), «Трубит, трубит погибельный рог» («Сорокоуст», 1920), «О Родина, счастливый и неисходный час!» («Октоих», 1917), «Отвори мне, страж заоблачный». И тут библейские мотивы как бы перенесены на русскую почву, приближены к русской ментальности и стали «своими». Отсюда мотивы странничества, изгнанничества и выход за пределы истории, и привязка к какой-то определенной земле:

\author{
Я, странник убогий, \\ Молюсь в синеву. \\ Древняя тень Маврикии \\ Родственна нашим холмам. \\ И это перекликается со строками Ф.И. Тютчева: \\ Удрученный ношей крестной, \\ Всю тебя, земля родная, \\ В рабском виде Царь Небесный \\ Исходил, благословляя ${ }^{30}$.
}

Отсюда - образы калек-перехожих, юродивых, благословение «тропинки, по коей нищий, я иду...». Это и приближение Пресвятой Богородицы и Св. Николая к русской действительности, и других святых, их русификация:

Кроют зори райский терем,

У окошка Божья Мать,

Голубей сзывает к дверям

Рожь зернистую клевать ${ }^{31}$.

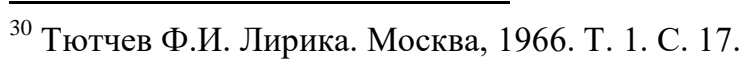


В шапке облачного скола, В лапоточках, словно тень, Ходит милостник Микола Мимо сел и деревень... Ходит странник по дорогам, Где зовут его в беде, И с земли гуторит с Богом В белой туче-бороде ${ }^{32}$.

Говорит Господь с престола, Приоткрыв окно за рай: «О мой верный друг, Микола, Обойди ты русский край. Защити там в черных бедах Скорбью вытерзанный люд, Помолись с ним о победах И за нищий их уют» ${ }^{33}$.

\section{ВЫВОДЫ}

Русская культура, искусство во всех областях стремились возродить древнерусские традиции, ее славное прошлое и таким образом идентифицировать себя как национальный тип. Иной раз это прошлое было связано с трагическими страницами истории (как многочисленные нашествия); иной раз в этом трагизме проявлялась сила духа народа (подвиги Александра Невского, Дмитрия Донского, Минина и Пожарского, Ивана Сусанина, Кутузова, Суворова, Ушакова), но оно созревало в народно-религиозном сознании и отражалось в произведениях искусства. Сказанное Ю. Лотманом о романах Ф. Достоевского: «Эсхатологический момент мгновенного и окончательного разрешения всех трагических противоречий жизни не привносится в эту жизнь извне из области идей, а обретается в ее собственной толще» ${ }^{34}$, применимо и к апокалиптической теме в русских операх, изнутри прочувствовавших «дух» русской истории. По мысли Г. Побережной, когда «времени осталось мало (а Апокалипсис обещает, что «скоро его совсем не будет»), тогда временной ток запечатлевается в сознании и сердце размеренном тревожным (как минимум - взволнованным) пульсом» ${ }^{35}$. Большинство произведений, несмотря на жанровые, авторско-стилистические отличия,

\footnotetext{
${ }^{31}$ Есенин С.А. Собрание сочинений : в 6 т. Москва, 1977-1980. Т. 2. С. 14.

32 Есенин С.А. Собрание сочинений : в 6 т. Москва, 1977-1980. Т. 2. С. 11, 12.

${ }_{33}$ Есенин С. А. Собрание сочинений : в 6 т. Москва, 1977-1980. Т. 2. С. 12. C. 232 .

Лотман Ю. Внутри мыслящих миров. Языки русской культуры. Тартуский университет, 1996.

35 Побережная Г. Художественный и сакральный аспекты музыкального метра. Метроритм - 1 . Киев, 2002. С. 88.
} 
имели нечто общее, объединяющее их, а именно стремление авторов в исторической и религиозной образности выразить и доказать свою национальную идентичность, верность традиции и, не отрекаясь от своего прошлого, оставаясь верными исторической правде, сохранить ее и передать следующим поколениям. В статье «Современное русское музыкознание и его исторические задачи» Б. Асафьев писал: «Исторически мы стоим на «перекрестке»: на Восток или на Запад?... Идея противопоставить себя Европе, научившись у нее же «ремеслу» исторически понятная идея. Музыке не избежать соприкосновения с ней. И потому, лично я и не предполагаю такой возможности, что ближайшее... поколение русских композиторов, совсем отвернувшись от европейской музыки, создало бы музыку на основе восточной системы интонирования, я считаю, что сама идея противопоставления со всеми вытекающими из нее положениями для русского музыкального творчества и музыкознания - жизненна и правдива... Обогащаясь сама, русская музыка оплодотворяет европейскую» ${ }^{36}$.

Именно искусство, запечатлевая определенные исторические моменты, помогает в какой-то степени противостоять явлениям фальсификации исторических событий. Русская культура как часть не только славянского, но и мирового культурного наследия принадлежит каждому человеку, считающему себя таковым, в противном случае он лишает себя права сопричастности к шедеврам мирового искусства: произведениям литературы, живописи, архитектуры, музыки. Если мы отказываемся читать Пушкина, Лермонтова. Достоевского, Толстого, слушать музыку Глинки, Мусоргского, Чайковского, Рахманинова, мы, прежде всего, обедняем самих себя. Как бы мы не относились к России или Советскому Союзу, гражданами которых мы являлись совсем недавно, мы не можем отрицать их как исторический факт. И осознанию себя, своей истории помогает искусство, на духовном и душевном уровне очищая души своих потомков от шелухи лжи и неправды, приближая их, таким образом, ко Творцу.

\section{АННОТАЦИЯ}

Статья посвящена выявлению исторических аспектов в русском искусстве рубежа XIX-XX веков. Пользуясь методами историкокультурологического, музыковедческого и жанрово-стилистического анализа, мы выявили характерную тенденцию в значительной части произведений русского искусства на рубеже XIX-XX веков: обращение к историческому прошлому как к символу национальной идентичности и заключение его в современный для авторов рассматриваемого периода

\footnotetext{
${ }^{36}$ Русская духовная музыка в документах и материалах. Москва : Знак, 2006. Том V : Александр Кастальский. Статьи, материалы, воспоминания, переписка. С. 295.
} 
«оклад». Изучение произведений данного периода является ценным и важным в нынешний рубежный период XX-XXI столетий, являясь своего рода духовным и интеллектуальным мостом между прошлым и будущим.

\section{ЛИТЕРАТУРА}

1. Асафьев Б. Музыкальная форма как процесс: Книги первая и вторая. 2-е изд. Ленинград : Музыка, 1971. 376 с.

2. Асафьев Б. Симфонические этюды. Ленинград : Музыка, 1970. 264 с.

3. Брянцева В. С.В. Рахманинов. Москва : Советский композитор, 1976. $645 \mathrm{c}$.

4. Гарднер И. Богослужебное пение русской Православной Церкви. Holy Trinity Monastery, Jordanville, 1977 2. Православный СвятоТихоновский Богословский институт : в 2 т. Москва, 2004. Том I : Сущность, система и история. 498 с; Том II : История. 527 с.

5. Есенин С.А. Собрание сочинений : в 6 т. Москва, 1977-1980.

6. Исаева И. О мелодической природе гармонии и фактуры Мусоргского. Вопросы теории музыки / ред.-составитель Т. Мюллер. Вып. 3. Москва : Музыка, 1975. С. 132-157.

7. Кукушкин Л. История Православия : в 3 ч. Харьков : Фолио, 2010. $893 \mathrm{c.}$

8. Лихачев Д. Великое наследие: Классические произведения литературы Древней Руси. Москва : Современник, 1980. 412 с.

9. Лосев А. Логика символа. Философия. Мифология. Культура. Москва : Искусство, 1991. 247 с.

10. Лотман Ю. Внутри мыслящих миров. Человек - Текст Семиосфера - История. Языки русской культуры. Тартуский университет, 1996. 447 с.

11. Назайкинский Е. Логика музыкальной композиции. Москва : Музыка, 1982.319c.

12. Орлов Г. Н.А. Римский-Корсаков на пороге XX века. Пути исканий. Вопросы теории и эстетики музыки. Вып. 14. Ленинград : Музыка, 1975. С. 7-30.

13. Осадчая С. Цикличность как ключевое свойство функционирования богослужебно-певческой традиции. Муз. мистеитво $i$ культура. Вип. 23. Одесса, 2016. С. 228-237.

14. Побережная $Г$. Художественный и сакральный аспекты музыкального метра. Метроритм - 1. Киев, 2002. С. 88-90.

15. Римский-Корсаков Н. Летопись моей музыкальной жизни. Девятое издание. Москва : Музыка, 1982. 440 с.

16. Русская духовная музыка в документах и материалах. Москва : Языки славянской культуры, 2002. Том IV : Степан Васильевич 
Смоленский. Воспоминания: Казань-Москва-Петербург / Гос. Центральный музей музыкальной культуры им. М.И. Глинки ; подгот. т-та, вступит. ст. и коммент. Н.И. Кабановой ; науч. ред. М.П. Рахманова. $688 \mathrm{c}$.

17. Русская духовная музыка в документах и материалах. Том V : Александр Кастальский. Статьи, материалы, воспоминания, переписка / Гос. ин-т искусствоведения, Гос. центральный музей музыкальной культуры им. М.И. Глинки ; ред.-сост., автор вступит. ст. и коммент. С.Г. Зверева. Москва : Знак, 2006. 1032 с., ил.

18. Ручьевская Е.А. Работы разных лет. Сборник статей : в 2 т. СанктПетербург : Композитор-Санкт-Петербург, 2011. Т. II : О вокальной музыке / отв. ред. В.В. Горячих. 504 с., нот.

19. Ситарская Ю. Религиозно-этическая проблематика и стилевые процессы в русской опере последней трети XIX - начала XX века: М. Мусоргский, Н. Римский-Корсаков : дисс. ... канд. искусствоведения. Киев, 2006. 196, нот. прил.

20. Тютчев Ф.И. Лирика. Москва, 1966. Т. 2.

21. Тышко С. Проблема национального стиля в русской опере. Глинка. Мусоргский. Бородин. Римский-Корсаков. Киев, 1993. 115 с.

22. Флоренский П. Богословские труды. Сборник 24. Москва : Издание Московской Патриархии, 1983. 248 с.

23. Шаляпин Ф. Страницы из моей жизни. Киев : Музична Україна, 1987. $326 \mathrm{c}$.

24. Шмеман Александр, протоиерей. Исторический путь Православия. Москва : Паломник, 2007. 400 с.

25. Шмеман А. Основы русской культуры : Беседы на Радио Свобода. 1970-1971 / протопресвитер Александр Шмеман ; сост. Е.Ю. Дорман ; предисл. О.А. Седакова ; подгот. текста и комм. М.А. Васильева, Е.Ю. Дорман, Ю.С. Терентьев. Москва : Издательство Православного Свято-Тихоновского гуманитарного университета, 2017. 416 с.

\section{Information about author: Dubrovskaya G. N.,}

Ph.D. in the History of Art, Assistant Professor at the Department of General and Specialize Piano Odessa National A. V. Nezhdanova Academy of Music 63, Novoselskogo str., Odessa, 65023, Ukraine 